Ryszard Nowicki

Bydgoszcz

\title{
Nieznany projekt rozporządzenia o zabezpieczeniu zbiorów bibliotecznych i odbudowie bibliotek w powojennej Polsce
}

Olbrzymie straty dóbr kultury, w tym księgozbiorów, poniesione przez Polskę podczas II wojny światowej, spowodowały konieczność odbudowy bibliotek i zbiorów bibliotecznych. Sprawa należała do wyjątkowo trudnych oraz skomplikowanych ze względu na ogrom zniszczeń. Pomimo dotkliwego zubożenia rodzimych zasobów część księgozbiorów przetrwała wojnę, m.in. w bibliotekach naukowych, publicznych, prywatnych. Na ziemie zachodniej Polski Niemcy zwozili w trakcie wojny wartościowe zbiory, m.in. z Berlina. Wartościowe materiały starali się ocalić przed spodziewanymi bombardowaniami. Ponadto na tych terenach przetrwała ogromna ilość księgozbiorów poniemieckiej proweniencji. Istniały również składnice, do których okupant kierował zagrabione książki z różnych regionów kraju, a także innych państw. Tak więc niezwłocznie należało podjąć czynności związane z ratowaniem dzieł pisanych. Zagrażało im bowiem bezmyślne zniszczenie, przywłaszczanie, oraz grabież w wyniku niekorzystnego zjawiska, określonego mianem szabru książek. Działania wojenne, jak również przemarsze wojsk przysporzyły dodatkowych uszczerbków. Część pozycji uległa spaleniu przez Armię Radziecką, bądź była wywożona, jako tzw. „materiał trofiejny”. $\mathrm{W}$ panującym powojennym chaosie czynności związane $\mathrm{z}$ ratowaniem woluminów nie należały do zadań łatwych. Ochroną zbiorów zajęły się różne ministerstwa, instytucje, stowarzyszenia, władze lokalne, organizacje społeczne i inne. Ze szkodą dla książek prace te nie były skoordy-

Artykuł powstał w ramach projektu sfinansowanego ze środków Narodowego Centrum Nauki, przyznanych na podstawie decyzji nr DEC2011/03/B/HS2/05446 
nowane. Dotkliwie brakowało zorganizowanych czynności w skali całego kraju. Największe osiągnięcia, w zakresie powojennej ochrony zbiorów bibliotecznych, odniosło Ministerstwo Oświaty, w wyniku realizacji centralnego planu nakreślonego przez Józefa Grycza ${ }^{1}$, od 1946 r. naczelnego dyrektora w Naczelnej Dyrekcji Bibliotek. Na szczególną uwagę zasługuje nieznany projekt podjęcia skoordynowanych działań, przygotowywany w 1944 r., w ramach mającego powstać Ministerstwa Oświaty i Kultury. Do utworzenia tej instytucji nie doszło. W strukturze Polskiego Komitetu Wyzwolenia Narodowego, w 1944 r. funkcjonowały odrębne resorty, tj. Resort Oświaty oraz Resort Kultury i Sztuki. Z dniem 1 stycznia 1945 r. przekształcone zostały w ministerstwa - Ministerstwo Oświaty i Ministerstwo Kultury i Sztuki.

Powróćmy do wspomnianej instytucji, która nie została utworzona, tj. Ministerstwa Oświaty i Kultury, i jej planu ochrony zbiorów. Nie czekając na zakończenie wojny, w 1944 r., powstał projekt rozporządzenia o zabezpieczeniu zbiorów bibliotecznych i odbudowie bibliotek ${ }^{2}$. Akt prawny postanowiło ogłosić Ministerstwo Oświaty i Kultury, w porozumieniu z Ministerstwem Spraw Wewnętrznych. Niezwykle interesujący dokument źródłowy jest przechowywany w zbiorach Biblioteki Narodowej. Tekst, pozbawiony datacji ${ }^{3}$, wykazuje dużą zbieżność z treścią Wskazówek dla prowadzących akcję zabezpieczenia bibliotek i zbiorów bibliotecznych autorstwa Józefa Grycza, pozycji ogłoszonej drukiem w 1945 r. Wiadomo, iż co najmniej od 1942 r. bibliolog kreślił plany powojennej ochrony zbiorów bibliotecznych. Świadczy o tym korespondencja J. Grycza skierowana do Adama Łysakowskiego ${ }^{4}$. Przypuszczalnie projekt rozporządzenia został zredagowany w 1944 r., na ziemiach polskich wolnych od okupacji niemieckiej. Być może autorem tekstu jest Józef Grycz. Z rozkazu Niemców, oraz za zgodą polskiego podziemia, kierował on od 27 lipca 1940 r. do 25 października 1944 r. tzw. Staatsbibliothek Warschau (Biblioteką Narodową). Pod koniec października tego roku wydostał się z obozu w Pruszkowie i wyjechał do Krakowa. Na po-

${ }^{1}$ Por. R. Nowicki, Rola Józefa Grycza w powojennej ochronie zbiorów bibliotecznych, „Z badań nad książką i księgozbiorami historycznymi”, 5:2011, s. 89-108.

${ }^{2}$ Projekt rozporzadzenia Ministerstwa Oświaty $i$ Kultury o zabezpieczeniu zbiorów bibliotecznych i odbudowie bibliotek - BN, Zakład Dokumentacji Księgoznawczej, Rewindykacje Księgozbiorów. Zabezpieczenie zbiorów, sygn. TD 141, [b. pag.].

${ }^{3} \mathrm{Na}$ dokumencie widnieje odręczny dopisek: Projekt z r. 1944.

${ }^{4}$ J. Grycz do A. Eysakowskiego, [Warszawa] 12 IV 1942, [w:] Bibliotekarstwo polskie 1925-1951 w świetle korespondencji jego wspóttwórców, wyboru z listów Adama Łysakowskiego, Mariana Łodyńskiego, Józefa Grycza i Heleny Hleb-Koszańskiej dokonała, wstępami, przypisami i indeksem opatrzyła M. Dembowska, Warszawa 1995, s. 274. 
czątku listopada powrócił do Pruszkowa. Kierował grupą zabezpieczającą oraz wywożącą zbiory biblioteczne z Warszawy. Na podkreślenie zasługuje fakt, iż w czasie wojny utrzymywał kontakt korespondencyjny z innymi ludźmi książki. Jego pomysł ratowania zbiorów był znany wąskiej grupie bibliologów. Na obecnym etapie badań nie udało się odszukać dodatkowych informacji pozwalających wskazać na autora (lub autorów) tekstu dokumentu. Projekt rozporządzenia mógł zostać napisany również przez Józefa Janiczka, jego współpracowników, bądź też członków przedwojennego Związku Bibliotekarzy Polskich przebywających na ziemiach wschodniej Polski. Nie natrafiono także na inne wersje, w tym ostateczną (czy powstała?), dokumentu. Być może zachowane unikatowe źródło stanowi jedyny ślad, związany z planami zorganizowanej w skali całego kraju powojennej ochrony zbiorów bibliotecznych, w ramach niezrealizowanej koncepcji utworzenia Ministerstwa Oświaty i Kultury.

Dokument (maszynopis $\mathrm{z}$ naniesionymi odręcznymi poprawkami) składa się z pięciu paragrafów ${ }^{5}$. W pierwszym nawiązano do zniszczeń księgozbiorów w okresie II wojny światowej. Zapowiadano otoczenie wszystkich zbiorów bibliotecznych szczególną opieką. Podkreślono wartość społeczną oraz znaczenie dzieł dla nauki i oświaty. Wyjaśniono, że akt prawny zostaje wydany celem zabezpieczenia i odbudowy zbiorów bibliotecznych. Dokument miał nabrać mocy urzędowej z chwilą oswobodzenia części kraju i obowiązywać do czasu zorganizowania władz ogólnokrajowej sieci bibliotecznej.

Kolejny paragraf informował o powierzeniu centralnego kierownictwa akcji zabezpieczenia i odbudowy bibliotek Naczelnemu Dyrektorowi Bibliotek w Ministerstwie Oświaty i Kultury. Wspomniano także o funduszach potrzebnych do prowadzenia działań w terenie.

W trzecim paragrafie znalazł się zapis dotyczący utworzenia na obszarze państwa, wokół ośmiu największych bibliotek, tymczasowych okręgów bibliotecznych. Bibliotece Narodowej wyznaczono zabezpieczanie księgozbiorów bibliotek naukowych w Warszawie. Ochronę zbiorów bibliotek powszechnych i szkolnych w stolicy powierzono Bibliotece Publicznej. Bibliotece Uniwersyteckiej w Warszawie miał podlegać obszar województw warszawskiego i lubelskiego; Bibliotece Miejskiej w Łodzi - województwa łódzkiego; Uniwersyteckiej w Wilnie - tereny województw wileńskiego, nowogródzkiego, poleskiego i białostockiego;

5 Paragraf szósty został odręcznie przekreślony. Może to świadczyć o trwaniu zaawansowanych prac redakcyjnych nad ostatecznym brzmieniem dokumentu. 
Uniwersyteckiej we Lwowie - województwa lwowskie, stanisławowskie, tarnopolskie i wołyńskie; Bibliotece Jagiellońskiej - województwa krakowskie, kieleckie i śląskie; Uniwersyteckiej w Poznaniu - województwa poznańskie i pomorskie.

Zabezpieczenie zbiorów i odbudowę bibliotek mieli organizować dyrektorzy wymienionych placówek, pełniący obowiązki okręgowych wizytatorów bibliotecznych, o czym informował paragraf czwarty. Jeżeli podlegający obszar obejmował dwa lub więcej województw, to wyznaczali oni bibliotecznych wizytatorów wojewódzkich. Do ich dyspozycji pozostawali wszyscy miejscowi bibliotekarze. Wizytatorzy organizowali zespoły biblioteczne, okręgowe oraz wojewódzkie komitety biblioteczne.

W paragrafie piątym wymienione zostały czynności związane z zabezpieczeniem i odbudową bibliotek. Miały one polegać na przygotowaniu spisu bibliotek istniejących przed wybuchem II wojny światowej, zabezpieczeniu i ochronie zbiorów z chwilą oswobodzenia części kraju, a także zbiórce książek pozostających bez opieki lub rozproszonych w wyznaczonych lokalach. Wskazywano sposoby odzyskiwania dzieł znajdujących się w posiadaniu prywatnym. Ponadto należało: zebrać wiadomości o stratach bibliotecznych, uporządkować zachowane zbiory, przeprowadzić podstawowe kursy biblioteczne, opracować wstępne plany organizacji bibliotecznej okręgu, w zależności od potrzeb poddać segregacji księgozbiory, uruchomić biblioteki, a także zebrać wszelkie druki wojenne $\mathrm{z}$ danego okręgu.

Zatem projekt zakładał dokonanie podziału Polski na okręgi biblioteczne. Znajdujemy w nim zapowiedź przyszłych rozwiązań prawnych regulujących powojenną ochroną księgozbiorów. W polskich realiach, w przygotowywanym brzmieniu, nie mógł nabrać mocy urzędowej. Autorzy tekstu nie mieli wówczas wystarczającej orientacji związanej z rozwojem wydarzeń politycznych i wiedzy dotyczącej nowego kształtu przyszłej Polski, bez ziem wschodnich. Dlatego też dodatkowe materiały, związane z próbą opracowania tego rozporządzenia, ze względów politycznych i obaw represyjnych, mogły nie przetrwać. Natomiast powojenna cenzura skazała dokument na zapomnienie.

Do pierwotnie niezrealizowanego zamysłu, tj. utworzenia okręgów bibliotecznych, dojdzie w Polsce w wyniku zarządzenia Ministra Oświaty Stanisława Skrzeszewskiego na początku 1945 r. W tym miejscu warto wspomnieć o czynnościach prawnych podjętych jeszcze w 1944 r. a związanych z ratowaniem księgozbiorów. Pierwszym dokumentem, w którym znalazła się informacja dotycząca ochrony zbiorów bibliotecznych, była odezwa kierownika PKWN, z 1 sierpnia 1944 r., skierowana do nauczy- 
cieli $^{6}$. Zostali oni wezwani do zabezpieczenia księgozbiorów oraz pojedynczych książek dla potrzeb szkół. Rozkaz nr 120 Naczelnego Dowódcy Wojska Polskiego z 22 listopada 1944 r. nakazywał żołnierzom poddać ochronie cenne podręczniki i dzieła naukowe ${ }^{7}$. W warunkach trwającej wojny wojskowi nie mieli możliwości prowadzenia zorganizowanych czynności ratujących zbiory. Wyjątkowo ważne systematyczne działania rozpoczął Resort Oświaty PKWN w Lublinie. W ramach tego Resortu, na początku listopada 1944 r., powstał projekt dekretu o zabezpieczaniu księgozbiorów opuszczonych ${ }^{8}$. Do uchwalenia dokumentu jednak nie doszło. Resort Oświaty 29 listopada 1944 r. wydał okólnik ${ }^{9}$, w którym obowiązek zabezpieczenia bibliotek i zbiorów bibliotecznych nałożył na władze szkolne I i II instancji. Inspektoraty oraz kuratoria zajęły się ratowaniem dzieł na terenach wolnych od okupacji niemieckiej. Podjęty zamysł był niewątpliwie słuszny. Zwłaszcza nauczyciele zdawali sobie sprawę z wagi i znaczenia słowa pisanego. Niestety, jak wynika z materiałów źródłowych, przedstawiciele oświaty nie zawsze jako pierwsi docierali do miejsc przechowywania woluminów. Reprezentanci innych instytucji, organizacji, czy też osoby prywatne okazali się szybsi. W skali całego kraju istniała nagląca potrzeba koordynacji działań przez jeden organ. Dlatego też Resort Oświaty skierował prośbę do innych resortów o przekazanie swych kompetencji w zakresie powojennej ochrony dzieł pisanych. Nieprzypadkowo jako pierwszy, 12 grudnia 1944 r., przekazał uprawnienia dotyczące zabezpieczenia zbiorów bibliotecznych Resort Kultury i Sztuki ${ }^{10}$. Zwłaszcza przedstawiciele tej instytucji zdawali sobie sprawę z wagi i znaczenia prac zmierzających do ratowania książek i odbudowy bibliotek. Byli oni doskonale zorientowani w podejmowanych czynnościach przez Resort Oświaty. Nie bez znaczenia pozostawały bowiem wcześniejsze wspólne wysiłki, związane z przygotowaniem rozporządzenia, w ramach planowanego Ministerstwa Oświaty i Kultury.

${ }^{6}$ A. Zielecki, Prawne uregulowania zabezpieczania księozbiorów opuszczonych i porzuconych w latach 1944-1945, [w:] Polska - Europa - Świat XX wieku. Studia i szkice ofiarowane Profesorowi Wtodzimierzowi Bonusiakowi w czterdziestolecie Jego pracy twórczej, pod red. Wacława Wierzbieńca, Rzeszów 2005, s. 709.

${ }^{7}$ Rozkaz nr 120 Naczelnego Dowódcy Wojska Polskiego z 22 XI 1944 r. - Warszawa, Centralne Archiwum Wojskowe, sygn. III.5.197, k. 36.

${ }^{8}$ J. Janiczek, Sprawy biblioteczne w ramach działalności Ministerstwa Oświaty, „Bibliotekarz", 13:1946, nr 1-2, s. 4.

${ }^{9}$ Okólnik Resortu Oświaty w sprawie zabezpieczenia bibliotek i zbiorów bibliotecznych, Nr Bibl. IV - W - 2195/44, „Dziennik Urzędowy Resortu Oświaty”, 1944, nr 1/4, poz. 32.

10 Okólnik Resortu Kultury i Sztuki z dnia 12 grudnia 1944 r. w sprawie przekazania spraw bibliotecznych inspektorom szkolnym - A. Knot, Polskie prawo biblioteczne, Wrocław-Warszawa 1947, s. 99-100. 
Projekt powołania kilku okręgowych kierowników bibliotecznych, i w związku z tym podziału Polski, został zrealizowany 15 lutego 1945 r. Przebywający w Krakowie dawni członkowie Związku Bibliotekarzy Polskich, doprowadzili do wydania przez Ministra Oświaty Stanisława Skrzeszewskiego zarządzenia, w sprawie zabezpieczenia bibliotek w województwach wolnych od niewoli hitlerowskiej ${ }^{11}$. Na mocy tego dokumentu minister ustanowił czterech okręgowych kierowników bibliotecznych. Do ich zadań należało przejmowanie oraz dalsza ochrona zbiorów bibliotecznych. Zostali nimi:

- dla woj. krakowskiego i kieleckiego - dyrektor Biblioteki Jagiellońskiej w Krakowie,

- dla woj. śląskiego - dyrektor Biblioteki Publicznej w Katowicach,

- dla woj. łódzkiego - dyrektor Biblioteki Miejskiej w Łodzi,

- dla woj. poznańskiego i pomorskiego - dyrektor Biblioteki Uniwersyteckiej w Poznaniu.

Zatem podstawą prawną rozpoczęcia prac okręgowych kierowników bibliotecznych było zarządzenie Stanisława Skrzeszewskiego. Zostali oni zobowiązani powiadomić społeczeństwo, na danym terenie, o treści ministerialnej decyzji. Interesujące informacje zawiera zarządzenie Ministra Oświaty z 15 lutego 1945 r., opublikowane w „Poznańskim Dzienniku Wojewódzkim"12, za sprawą jednego z okręgowych kierowników bibliotecznych, to jest Aleksandra Birkenmajera. Z treści dokumentu wynika, że w okręgu województw poznańskiego i pomorskiego kierownictwo akcji zabezpieczenia bibliotek i zbiorów bibliotecznych minister powierzył dyrektorowi Biblioteki Uniwersyteckiej w Poznaniu, działającemu przy pomocy upoważnionych przez siebie bibliotekarzy. Do jego zadań należało:

1. zebranie wiadomości o wszelkich istniejących bibliotekach oraz o wojennych stratach bibliotecznych,

2. zabezpieczenie na miejscu, lub w lokalach przez niego wyznaczonych, wszelkich bibliotek (z wyjątkiem księgozbiorów domowych służących do osobistego użytku właścicieli), a zwłaszcza zbiorów bibliotecznych zgłoszonych do ochrony lub pozostawionych bez opieki,

${ }^{11}$ Minister Oświaty do Ministra Rolnictwa i Reform Rolnych $w$ Warszawie w sprawie zabezpieczenia bibliotek, Kraków 15 lutego 1945 r. [odpis] - Poznań, Archiwum Biblioteki Uniwersytetu Poznańskiego, Referat zabezpieczania i segregacji zbiorów. Zarządzenia, instrukcje i upoważnienia1944-1946, sygn. 535, k. 13.

12 Zarzadzenie Ministra Oświaty $z$ dnia 15 lutego 1945 r.w sprawie zabezpieczenia bibliotek, „Poznański Dziennik Wojewódzki”, 1945, nr 3, poz. 17. 
3. zebranie książek rozproszonych oraz wszelkiego rodzaju dokumentów wojennych, z wyjątkiem archiwaliów,

4. segregowanie według przydatności książek dla różnych typów bibliotek i inwentaryzowanie zgromadzonych materiałów,

5. porozumienie się $\mathrm{w}$ sprawie zabezpieczenia bibliotek $\mathrm{z}$ innymi władzami państwowymi (tj. Kuratorium Okręgu Szkolnego, Wojewódzkim Oddziałem Kultury i Sztuki, Wojewódzkim Urzędem Ziemskim) i samorządowymi.

Powyższe zadania zostały przydzielone również pozostałym okręgowym kierownikom bibliotecznym. Należy stwierdzić, że zakres czynności wykazuje dużą zgodność z projektem rozporządzenia z 1944 r. Wśród autorów tekstu zarządzenia z 1945 r. mogli znajdować się twórcy wcześniejszego dokumentu lub osoby doskonale znające jego treść. Liczba okręgów, ze względu na nowy kształt Polski, uległa zmniejszeniu. Tylko dwa $\mathrm{z}$ nich będą obejmowały obszary przewidziane w projekcie z 1944 r., tj. podlegający dyrektorom Biblioteki Uniwersyteckiej w Poznaniu oraz Biblioteki Miejskiej w Lodzi. Bibliotekom warszawskim, wobec ogromu strat i zniszczeń stolicy, nie powierzono w zarządzeniu ministerialnym obowiązków zabezpieczania zbiorów bibliotecznych. Po raz pierwszy natomiast do ratowania księgozbiorów wskazano Bibliotekę Śląską w Katowicach, której wyznaczono teren województwa śląskiego (pierwotnie obszar ten miał podlegać Bibliotece Jagiellońskiej).

Zarządzenie zostało ogłoszone $\mathrm{w}$ trudnym momencie - na terenie kraju nadal trwały zacięte walki z Niemcami. Dlatego też w dokumencie jedynie ogólnie wymieniono obszary poszczególnych okręgów. Nieznany był wówczas ostateczny kształt przyszłej Polski oraz podział administracyjny kraju. Część kierowników nie mogła rozpocząć pracy, gdyż tereny nadal zajmował okupant. Po wyparciu wroga zabezpieczaniem zajęły się miejscowe czynniki. Wobec tego dopiero po przybyciu okręgowych kierowników można było przystąpić, w sposób zorganizowany, do ratowania zbiorów.

Decyzja ministra Stanisława Skrzeszewskiego nie zapobiegła konfliktom w terenie. Do sporu doszło pomiędzy Biblioteką Jagiellońską a Kuratorium Szkolnym w Kielcach. Ich powodem stało się nakładanie kompetencji. Nie wzięto bowiem pod uwagę faktu, przy wydaniu zarządzenia z 15 lutego 1945 r., że obowiązek ratowania dzieł już wcześniej został nałożony na władze szkolne I i II instancji. Okólnik Resortu Oświaty z 29 listopada 1944 r. nie tracił swojej mocy prawnej. Sprawa ochrony zbiorów spoczywała na kuratoriach i inspektoratach szkolnych oraz kie- 
rownikach kilku bibliotek, w tym początkowo dwóch uniwersyteckich ${ }^{13}$. Z treści listu Józefa Grycza do Aleksandra Birkenmajera, z 13 kwietnia 1945 r., wynika, iż w Ministerstwie Oświaty dostrzeżono powstały problem $^{14}$. Wiosną tego roku gotowe było nawet pismo, przygotowane przez Józefa Janiczka, uchylające zarządzenie Stanisława Skrzeszewskiego, w odniesieniu do bibliotek uniwersyteckich. Prawdopodobnie nie został jednak nadany dalszy bieg służbowy tej sprawie. Dyrektorzy bibliotek uniwersyteckich nadal aktywnie uczestniczyli w ratowaniu zbiorów, a wkrótce dołączyli kolejni. Z ramienia Ministerstwa Oświaty na Dolnym Śląsku ochroną zbiorów będzie kierował dyrektor Biblioteki Uniwersyteckiej we Wrocławiu Antoni Knot, a dyrektor Biblioteki Uniwersyteckiej w Toruniu Stefan Burhardt, ze zwiezionych zbiorów zabezpieczonych, stworzy podstawę księgozbioru nowopowstałej placówki naukowej.

Sytuacje konfliktowe, związane z wydanym 15 lutego zarządzeniem, występowały także i w innych zakątkach kraju. Konieczna była w tym zakresie współpraca. Dochodziło do niej. Kuratoria oraz inspektoraty szkolne informowały o zbiorach zabezpieczonych na swoim terenie i przekazywały woluminy delegatom okręgowych kierowników bibliotecznych. Za pośrednictwem kuratoriów, okręgowi kierownicy otrzymywali część środków finansowych, przekazywanych przez Ministerstwo Oświaty, potrzebnych do prowadzenia prac i zwożenia księgozbiorów. Zarówno władze szkolne, jak i kierownicy, działali na rzecz wspólnej sprawy, tj. ratowania książek i odbudowy bibliotek. Przykładowo na obszarze Wielkopolski współpraca pomiędzy okręgowym kierownikiem bibliotecznym Aleksandrem Birkenmajerem a Kuratorium Okręgu Szkolnego Poznańskiego przebiegała sprawnie. Wspólnie m.in. zorganizowano zbiórkę książek poniemieckich, trwającą od 25 kwietnia do 1 maja 1945 r., na terenie Poznania. Delegat Ministerstwa Oświaty na Okręg Szkolny Poznański Karol Strzałkowski, w piśmie skierowanym do dyrekcji szkół średnich i inspektoratu szkolnego, informował o zorganizowaniu, przez Kuratorium i Bibliotekę Uniwersytecką, tygodnia zbiórki książek niemieckich ${ }^{15}$. Celem działań była ochrona cennych dzieł nau-

131 grudnia 1945 r. zostanie ustanowiony Delegat Ministerstwa Oświaty w Krakowie Stanisław Sierotwiński, któremu podlegał obszar kraju podzielony na sześć okręgów: I Krakowski, II Wrocławski, III Szczeciński, IV Gdański, V Olsztyński i VI Lubuski - zob. R. Nowicki, Stanistaw Sierotwiński w latach 1945-1946 jako delegat Ministerstwa Oświaty do zabezpieczania ksieggozbiorów opuszczonych i porzuconych na ziemiach zachodnich, „Roczniki Biblioteczne”, 50:2006, s. 13-44.

${ }^{14}$ J. Grycz do A. Birkenmajera, Warszawa, 13 IV 1945 r. - BJ, rps przyb. 572/75.

${ }^{15}$ Pismo Kuratorium Okregu szkolnego Poznańskiego, Nr II-1675/45, w sprawie zbiórki ksiażek niemieckich, Poznań 23 kwietnia 1945 r. - Poznań, Archiwum Biblioteki Uniwer- 
kowych przed bezmyślnym zniszczeniem. Odszukane książki przez młodzież w ich domach prywatnych, a także mieszkaniach krewnych i sąsiadów, należało przekazywać do kilku punktów zbiorczych, tj.: Biblioteki Uniwersyteckiej, przy ul. Ratajczaka, Ogólnej Administracji Uniwersytetu Poznańskiego, przy ul. Słowackiego, i Bratniej pomocy Studentów Uniwersytetu Poznańskiego, przy ul. Grunwaldzkiej.

Wydane zarządzenie, o powołaniu okręgowych kierowników bibliotecznych, nie oznaczało skupienia przez Ministerstwo Oświaty wszystkich spraw związanych $\mathrm{z}$ ochroną zbiorów. W terenie wystąpiły i inne problemy. Na przykład kierownik okręgu śląskiego Paweł Rybicki nie mógł rozpocząć zabezpieczania księgozbiorów podworskich, ponieważ kompetencje w tym zakresie, zgodnie z dekretem z dnia 2 marca 1945 r. o majątkach opuszczonych i porzuconych, należały do Tymczasowego Zarządu Państwowego ${ }^{16}$. Dlatego też 27 kwietnia 1945 r. dyrektor Śląskiej Biblioteki Publicznej skierował do Tymczasowego Zarządu Państwowego w Katowicach prośbę o wydanie stosownego upoważnienia ${ }^{17}$. Na początku maja wysłał ${ }^{18}$ odpisy pisma Ministra Oświaty do Ministerstwa Rolnictwa i Reform Rolnych (z 15 lutego 1945 r.) ${ }^{19}$, a także własną delegację wystawioną przez tę pierwszą instytucję. Starania zakończyły się sukcesem. 8 czerwca 1945 r. otrzymał zgodę na zabezpieczanie bibliotek opuszczonych i porzuconych w województwie śląsko-dąbrowskim ${ }^{20}$.

Należy stwierdzić, że zachowany projekt rozporządzenia o ochronie księgozbiorów, z 1944 r., jest niezwykle ważny do poznania genezy powojennej ochrony zbiorów bibliotecznych w Polsce. Główne czynności związane z ratowaniem zbiorów trwały w kraju do 1949 r. a ostatecznie

syteckiej, Referat Zabezpieczania i segregacji księgozbiorów. Akcja rewindykacji (korespondencja) 1945-1946, sygn. 544, k. 74.

16 Dekret $z$ dnia 2 III 1945 r. o majątkach opuszczonych i porzuconych, Dz.U., Nr 9, poz. 45.

${ }^{17}$ P. Rybicki do Tymczasowego Zarządu Państwowego w Katowicach, Katowice 27 IV 1945 r. - Katowice, Archiwum Biblioteki Śląskiej, Biblioteka Śląsa w Katowicach. Dziat Uzupetniania Zbiorów. Wykazy księgozbiorów pozostałości poniemieckiej 1945, [b. sygn. i pag.].

18 P. Rybicki do Tymczasowego Zarządu Państwowego w Katowicach, Katowice 7 V 1945 r. - tamże.

${ }^{19}$ Minister Oświaty Stanisław Skrzeszewski prosił Ministerstwo Rolnictwa i Reform Rolnych o wydanie podległym organom polecenia, by przy obejmowaniu majątków ziemskich zabezpieczały czasowo biblioteki i zawiadamiały o ich istnieniu okręgowych kierowników bibliotecznych, do których zadań należy przejęcie i dalsza ochrona zbiorów.

20 Tymczasowy Zarząd Państwowy na Województwo Śląsko-Dąbrowskie do P. Rybickiego, Katowice 8 VI 1945 r. - Katowice, Archiwum Biblioteki Śląskiej, Biblioteka Ślaska w Katowicach. Dziat Uzupetniania Zbiorów. Wykazy księgozbiorów pozostałości poniemieckiej 1945, [b. sygn. i pag.]. 
zakończyły w 1955 r., wraz z likwidacją Zbiornicy Księgozbiorów Zabezpieczonych w Katowicach. Skoordynowane działania miało wprowadzić w życie Ministerstwo Oświaty i Kultury - instytucja, która nie powstała. Treść dokumentu stanowiła zapowiedź podziału kraju na kilka okręgów bibliotecznych, w tym obejmujących przedwojenne obszary wschodniej Polski, z Wilnem i Lwowem. Pracami w terenie mieli kierować dyrektorzy dużych bibliotek. Ze względów politycznych oraz zmianę powojennych granic Polski pierwotny projekt nie został wprowadzony w życie. Przez długie lata skazany został na zapomnienie, m.in. ze względu na panującą cenzurę. Stanowił on zapowiedź zarządzenia Ministra Oświaty Stanisława Skrzeszewskiego, wydanego 15 lutego 1945 r. w Krakowie, podziału Polski na cztery okręgi biblioteczne, którymi kierowali dyrektorzy dużych bibliotek. Niezwykle cenny dokument źródłowy, przechowywany w zbiorach Biblioteki Narodowej w Warszawie, stanowi dowód troski i starań, związanych z ratowaniem dzieł pisanych, w sposób centralny i zorganizowany. Jest pierwszą próbą regulacji prawnej wyjątkowo złożonych spraw związanych z powojenną ochroną zbiorów bibliotecznych i odbudowy bibliotek.

\begin{abstract}
ANEKS
Projekt rozporządzenia o zabezpieczeniu zbiorów bibliotecznych i odbudowie bibliotek [1944 r.]
\end{abstract}

Źródło: BN, Zakład Dokumentacji Księgoznawczej, Rewindykacje Księgozbiorów. Zabezpieczenie zbiorów, sygn. TD 141, [b. pag].

Rozporządzenie

Ministra Oświaty i Kultury z dnia...

o zabezpieczeniu zbiorów bibliotecznych i odbudowie bibliotek wydane w porozumieniu z Ministerstwem Spraw Wewnętrznych

$\S 1$. Wobec zniszczenia bibliotek i książek w okresie wojennym oraz ze względu na ich wartość społeczną i znaczenie w planowej organizacji nauki i oświaty, biorę pod szczególną opiekę wszelkie zbiory biblioteczne - na obszarze Państwa i wydaję celem zabezpieczenia i odbudowy 
tych zbiorów następujące zarządzenia, które wchodzą w życie z chwilą oswobodzenia kraju lub jego części i są ważne do czasu zorganizowania władz ogólnokrajowej sieci bibliotecznej.

$\S 2$. Centralne kierownictwo akcji zabezpieczenia i odbudowy bibliotek powierzam Naczelnemu Dyrektorowi Bibliotek w Ministerstwie Oświaty i Kultury, który według ustalonych tu zasad zarządza działalnością w terenie i dysponuje potrzebnymi na ten cel funduszami.

$\S 3$. Na obszarze Państwa tworzę tymczasowe okręgi biblioteczne wokół największych bibliotek, które przetrwały w swoich gmachach i choć z częścią swych pracowników, wobec czego są zdolne podjąć pierwszą akcję, a mianowicie:

Biblioteka Narodowa J.[ózefa] P.[iłsudskiego] w Warszawie zabezpiecza zbiory bibliotek naukowych $\mathrm{m}$. st. Warszawy,

[Biblioteka] Publiczna [w Warszawie zabezpiecza] zbiory bibliotek powszechnych i szkolnych m.st. Warszawy,

[Biblioteka] Uniwersytecka [w Warszawie] zabezpiecza zbiory bibliotek województwa warszawskiego i lubelskiego,

[Biblioteka] Miejska w Łodzi zabezpiecza zbiory bibliotek wojew. łódzkiego,

[Biblioteka] Uniwersytecka w Wilnie zabezpiecza zbiory bibliotek ${ }^{21}$ wojew. wileńskiego[,] nowogródzkiego, poleskiego i białostockiego.

[Biblioteka Uniwersytecka] we Lwowie [zabezpiecza] zbiory bibliotek wojew. lwowskiego, stanisławowskiego, tarnopolskiego i wołyńskiego ${ }^{22}$,

[Biblioteka] Jagiellońska [w] Krakowie [zabezpiecza] zbiory bibliotek wojew. krakowskiego, kieleckiego i śląskiego,

[Biblioteka] Uniwersytecka [w] Poznaniu [zabezpiecza] zbiory bibliotek wojew. poznańskiego i pomorskiego.

$\S 4$. Zabezpieczenie i odbudowę w wymienionych okręgach organizują dyrektorzy powołanych bibliotek, jako p.o. okręgowych wizytatorów bibliotecznych. Gdy okręg obejmuje dwa lub więcej województw, wyznaczają oni spośród bibliotekarzy, znajdujących się na danym obszarze, z uwzględnieniem fachowego kierunku ich dotychczasowej działalności, podległych sobie p.o. bibliotecznych wizytatorów wojewódzkich i w miarę możności powierzają akcję największej bibliotece na terenie poszczególnych województw. Do dyspozycji wizytatorów pozostają przy tym wszyscy miejscowi bibliotekarze - państwowych, samorządowych, ewent. innych bibliotek. Zarówno naukowych, jak powszechnych. Wizytatorzy biblio-

\footnotetext{
${ }^{21}$ Wyraz dopisany odręcznie.

22 Uwaga jak wyżej.
} 
teczni organizują wreszcie spośród właścicieli lub kierowników większych bibliotek okręgu, przedstawicieli zespołów bibliotecznych, zawodowej organizacji bibliotekarzy oraz odpowiednich władz - okręgowe lub wojewódzkie komitety biblioteczne celem uzgadniania akcji wedle potrzeby.

O wydanych zarządzeniach i przebiegu prac komunikują wizytatorzy okręgowi jak najspieszniej Naczelnemu Dyrektorowi Bibliotek.

$\S 5$. Zabezpieczenie i odbudowa bibliotek obejmuje następujące czynności:

a) przygotowanie spisu bibliotek, które istniały na terenie okręgu w r. 1939 lub w czasie wojny,

b) zabezpieczenie zbiorów - w momencie oswobodzenia kraju przed możliwymi szkodami[,] bądź to przez zapewnienie większym bibliotekom bezpośredniej i stałej opieki bibliotekarzy, bądź też - w mniejszych miastach i wsiach - drogą uzyskania pomocy władz administracyjnych lub szkolnych, czy poszczególnych szkół, zarządów gminnych lub sołtysów,

c) zbiórka i przechowanie pozostających bez opieki lub rozproszonych książek w wyznaczonych do tego lokalach (bibliotek, szkół, zarządów gminnych) w obrębie każdej miejscowości,

d) odzyskanie książek z rąk prywatnych dwiema drogami:

1. przez odezwę (w prasie) do społeczeństwa i do księgarń o zwrot książek należących do bibliotek publicznych i społecznych, a wypożyczonych przed wojną, tymczasowo przechowywanych, albo w czasie wojny nabytych,

2. przez użycie pomocy władz administracyjnych (dokonanie rewizji) wobec osób, które sobie takie książki nieprawnie przywłaszczyły;

e) zebranie wiadomości o stratach bibliotek przedwojennych w księgozbiorze, katalogach, urządzeniach bibliotecznych i lokalu, jako też o stratach pracowników biblioteki oraz zgromadzenia dowodów i protokołów tych strat,

f) uporządkowanie zachowanych bibliotek przez sprawdzenie ich inwentarza lub uporządkowanie książek zebranych, ich tymczasowe ustawienie, spisanie (w 2 egz.) i posygnowanie,

g) urządzenie krótkich kursów dla przeszkolenia inwentaryzatorów (spośród młodzieży akademickiej, członków organizacji społecznych, nauczycieli) w zakresie działań bibliotecznych przewidzianych w niniejszym rozporządzeniu - celem obsłużenia różnych bibliotek i miejsc zbiórki bibliotecznej,

h) opracowanie - w porozumieniu $\mathrm{z}$ właścicielami bibliotek - wstępnego planu przyszłej organizacji bibliotecznej okręgu z uwzglę- 
dnieniem możliwości odtworzenia zniszczonych bibliotek oraz znaczenia ich tradycji i roli w projektowanej sieci bibliotecznej,

i) na tej podstawie - segregacja materiału dyspozycyjnego i dopełnianie, scalanie lub wymiana księgozbiorów,

j) wreszcie uruchomienie i udostępnienie czytelnikom zachowanych bibliotek,

k) dodatkowo należy połączyć z tą akcją jak najspieszniejsze starania o zgromadzenie kompletu wszelakich druków wojennych (prasy tajnej, ulotek, plakatów, wycinków) z terenu danego okręgu przez ogłoszenie odezwy do społeczeństwa, zabiegi u prywatnych zbieraczy, styczność z drukarniami, kupno itp. ${ }^{23}$

\section{Streszczenie}

\section{Nieznany projekt rozporządzenia o zabezpieczeniu zbiorów bibliotecznych i odbudowie bibliotek w powojennej Polsce}

Olbrzymie straty dóbr kultury, w tym księgozbiorów, poniesione przez Polskę podczas II wojny światowej, spowodowały konieczność odbudowy bibliotek i zbiorów bibliotecznych. Sprawa należała do wyjątkowo skomplikowanych ze względu na ogrom zniszczeń. Jeszcze w trakcie działań wojennych, w 1944 r., powstał projekt rozporządzenia o ochronie księgozbiorów. Skoordynowane działania miało wprowadzić w życie Ministerstwo Oświaty i Kultury - instytucja, która nie powstała. Treść dokumentu stanowiła zapowiedź podziału kraju na kilka okręgów bibliotecznych, w tym obejmujących przedwojenne obszary wschodniej Polski, z Wilnem i Lwowem. Pracami w terenie mieli kierować dyrektorzy dużych bibliotek. Ze względów politycznych oraz zmianę powojennych granic Polski pierwotny projekt nie został wprowadzony w życie. Stanowił on zapowiedź zarządzenia Ministra Oświaty Stanisława Skrzeszewskiego, wydanego 15 lutego 1945 r. w Krakowie, podziału Polski na cztery okręgi biblioteczne, którymi kierowali dyrektorzy dużych bibliotek. Niezwykle cenny dokument źródłowy, przechowywany w zbiorach Biblioteki Narodowej w Warszawie, stanowi dowód troski i starań, związanych z ratowaniem dzieł pisanych, w sposób centralny i zorganizowany. Jest pierwszą próbą regulacji prawnej niezwykle złożonych spraw związanych z powojenną ochroną zbiorów bibliotecznych i odbudowy bibliotek.

${ }^{23}$ Projekt zawierał $\S 6$, odręcznie skreślony, o następującym brzmieniu: „W akcji zabezpieczenia i odbudowy bibliotek powierzam zawodowej organizacji bibliotekarzy zadanie budzenia w społeczeństwie zrozumienia dla potrzeb urządzenia i udostępnienia przede wszystkim bibliotek publicznych i przekazanie im w zamian za odpowiedni ekwiwalent zruszonych z dawnego ładu zbiorów zamkniętych bibliotek prywatnych i stowarzyszeniowych". 


\section{Summary}

\section{An Unknown Draft of a Regulation Concerning the Safekeeping of Book Collections and the Reconstruction of Libraries in Post-War Poland}

In the face of unprecedented losses in the Polish cultural substance - including book collections - during the Second World War, reconstruction of libraries and their holdings when the hostilities ceased, attained utmost importance. The issue was particularly complicated because of the amount of annihilated books. Already in 1944, before the final collapse of the Third Reich, a draft of a governmental regulation concerning the safekeeping of extant book collections was prepared. The document foresaw coordinated efforts by the Ministry of Enlightenment and Culture - an institution that eventually never came into being. The draft postulated a divide the country into several library regions, which encompassed the eastern territories of pre-war Poland, with Vilnius and Lviv. Activities in thus constituted regions were to be coordinated by directors of great research libraries. Due to political reasons and the changes in post-war Polish boundaries this draft never became law. It only anticipated the regulation issued by Minister of Enlightenment Stanisław Skrzeszewski on 15 February 1945 in Cracow, which divided Poland into four library regions, which in fact were to be directed by heads of major research libraries. The aforementioned draft, extant in the archives of the Polish National Library in Warsaw, brings forward important evidence of the efforts aimed at rescuing printed and manuscript materials in a coordinated, organized fashion. It was the first attempt at such a regulation of post-war library reconstruction, undertaken at a time of most complicated political situation. 